DOI https://doi.org/10.18551/rjoas.2017-02.14

\title{
THE PERSPECTIVE OF THE AGENCY THEORY IN BUDGET PREPARATION OF LOCAL GOVERNMENT AND ITS IMPLEMENTATION ON BUDGET PERFORMANCE AND FINANCIAL DECENTRALIZATION TO REALIZE PERFORMANCE OF LOCAL GOVERNMENT OF REGENCIES AND CITIES IN BANTEN PROVINCE
}

\author{
Marwan Jubery* \\ ${ }^{1}$ Doctoral Program of Management, Faculty of Economics and Business, Universitas \\ Brawijaya, Indonesia \\ Moeljadi, Ananda Candra Fajri, Djazuli Atim \\ ${ }^{2}$ Faculty of Economics and Business, University of Brawijaya, Indonesia \\ *E-mail: marwanjubery@gmail.com
}

\begin{abstract}
The purpose of this study is to examine and analyze the perspective of the Agency Theory in the formulation and implementation of local government budgets. This research was conducted at regencies / cities in Banten employing survey method and regression analysis in hypothesis testing. The population was all regencies / cities in Banten. Selection of the sample was the entire population (census). Data consisted of secondary data and was classified as panel data; covering the cross section and time series data. Sources of data were from DPKD ${ }^{1}$, Bappeda ${ }^{2}$ at regencies and cities, and the Central Bureau of Statistics in Banten from 2009 to 2014. The analysis was done using Path Analysis and Partial Least Square (PLS). The findings indicate that: (1) the change of $\mathrm{PAD}^{3}$ does not affect the Opportunistic Behavior of the Legislators; (2) the amendment to the Budget of DPRD ${ }^{4}$ positively affects the Opportunistic Behavior of the Legislators; (3) budget decentralization affects Regional Financial Performance; (4) budget decentralization does not affect the Local Government Performance; and (5) Regional Financial Performance affects Local Government Performance. Analysis on the Agency Theory Perspective shows that: (1) budget allocated for DPRD and infrastructure has increased, while budget on health and education has decreased; this indicates the Opportunistic Behavior of Legislators; and (2) when it comes to budget policies, the executive and legislative tend to practice moral hazard for their own self-interest; the fact reveals much bigger compared to development expenditures in $\mathrm{APBD}^{5}$. The decisions are related to the contracts given to outside parties, which can produce rente ${ }^{6}$ in the form of commissions.
\end{abstract}

\section{KEY WORDS}

The perspective of the Agency Theory in public budgeting, opportunistic behavior of the legislators, decentralized budget, regional financial performance, local government performance

Opportunistic behavior may occur at all levels of public budgeting, from the planning to the payment of public funds. Political corruption may occur in the local budgeting process where political decisions are very dominant, done by diverting public resources allocation (Garamfalvi, 1997). Corruption in the implementation of the budget is administrative corruption as administrative decision is more dominant. In the end, political corruption will lead to administrative corruption. Opportunistic behavior brings much impact on budget allocation decisions for capital projects (Tanzi and Davoodi, 2002).

\footnotetext{
Dinas Pengelolaan Keuangan dan Aset Daerah, translated as the Office for Management of Regional Finance and Assets.

Badan Perencanaan Pembangunan Daerah, translated as Development Planning Agency at Sub-National Level.

${ }^{3}$ Pendapatan Asli Daerah, translated as Locally Generated Revenue.

${ }^{4}$ Dewan Perakilan Rakyat Daerah, translated as Regional House of Representative.

Anggaran Pendapatan dan Belanja Daerah, translated as Local Revenue and Expenditure or Local Budget.

Some kind of interests.
} 
Opportunistic behavior of politicians in decision-making related to public investment is caused by decisions related to (1) the amount of the public investment, (2) the composition of the public investment, (3) the selection of specific projects and location, and (4) the design of each public investment project. The decisions are related to the contracts given to outside parties, which can produce rente in the form of commissions. Thus, corruption would increase the number, magnitude, and complexity of the projects, causing: (1) an increase in the ratio of public investment to GDP; (2) a decrease in the productivity of public investment; (3) a reduction in the allocation for public services budget; and (4) a decline in economic growth (Tanzi and Davoodi, 2002).

Inappropriate political representation and weak institutions lead to many opportunities for political corruption. The findings of Abdullah and Asmara (2006) show that legislators in some local governments in Indonesia show opportunistic behavior in the budgeting process; they use the process for political corruption. Therefore, to explain the phenomenon of selfinterest in the public budgeting, Agency Theory can be used as a theoretical basis (Christensen, 1992; Johnson, 1994; Smith and Bertozzi, 1998).

The perspective of Agency Theory in the formulation and implementation of local government budgets in essence sees how people vote for politicians to make public policy and they provide the funds by paying the tax (Von Hagen, 2002). The politicians should represent the interests of the people in budget allocation. In fact, the legislators do not always have the same preferences with the public (Groehendijk, 1997). Therefore, Lupia and Mc Cubbins, 2000 warn that the delegation of authority has the consequences of abdication. The issue of abdication becomes more real when there is no formal institution that serves to supervise the performance of legislators.

The role of the central government towards fiscal decentralization policy is considered a way out for the welfare of the community, because local governments know the actual priorities or the main programs in implementing the budget for the welfare of the society (Musgrave, 1959; Oates, 1993). Granting fiscal authority and transfer of funds by the central government is intended to enable local finance and authority for the area to manage all local financial potential optimally.

Budget decentralization does not affect the performance of local governments. Budget decentralization can actually create an opportunity for local governments to undertake less responsible and less sustainable spending, if it is done without institutional readiness of administration and bureaucracy as well as adequate human resources (Phillips and Woller, 1997). The findings are supported by Stephen and Russek (1997) on the impact of the fiscal structure on economic growth. First, the increase in the budget surplus will boost economic growth, when spending on education or public transport can be reduced or corporate income tax can be increased. Second, if the sales tax and other taxes are used for transfer payment, then economic growth will decrease, but if corporate income tax is used for transfer payment then economic growth will increase. Third, tax will negatively affect economic growth when state revenue is used to fund education, public transportation, and public safety. Those findings show that economic growth happens when fiscal is intended to increase income tax and sales tax, but not to community service.

Decentralization is expected to encourage the local experience of the local government, by studying the experience of other regions in the implementation of decentralization (Musgrave, 1959; Oates, 1993). This also will realize local accountability, i.e. to encourage local governments to be able to distribute and allocate resources to the welfare of society by taking into account the rights of its people. Rights of these communities include service to the community, especially health care, education, and infrastructure.

\section{THEORETICAL AND HYPOTHETICAL REVIEW}

The Perspective of the Agency Theory in the Process of Local Government Budget. The rationality in the Agency Theory is as follows. The principal makes a contract with the agency, either implicitly or explicitly, in the hope that the agency will do the job as desired by the principal. Agents are considered to have a lot of information about actual performance, 
budget management, motivation, and real purpose. Executives want to maximize their budgets in the formulation and implementation of local government budgets, but in reality, the executive tends to do "budgetary slack" and leads to the misallocation of the budget for their own benefit (self-interest). This potentially creates moral hazard and adverse selection. The tendency of misallocation in government spending is part of a political battle between the politicians and executives, which never benefit the poor. When the allocation decisions are made, their motivation to output budget is rent seeking. The preference of the legislators (DPRD) is over their own budget and infrastructure projects because it is easier to use for the fulfillment of the promise to their voters (Keefer and Khemani, 2003).

The Perspective of the Agency Theory in the Implementation of Local Government Budget. The perspective of the Agency Theory on Local Government Budget Implementation quantitatively and structurally can be analyzed through policies that have been taken in local government budgeting process previously associated with decision-making: (1) the amount of the public investment, (2) the composition of the public investment, (3) the selection of specific projects and location, and (4) the design of each public investment project. The decisions are related to the contracts given to outside parties, which can produce rente in the form of commissions.

\section{RESEARCH FRAMEWORK AND OPERATIONAL VARIABLE}

According to Garamfalvi (1997), corruption can occur at all levels of budgeting, from planning to the payment of public funds. Political corruption may occur in the local budgeting process where political decisions are very dominant, done by diverting public resources allocation. Corruption in the implementation of the budget is administrative corruption as administrative decision is more dominant. In the end, political corruption will lead to administrative corruption.
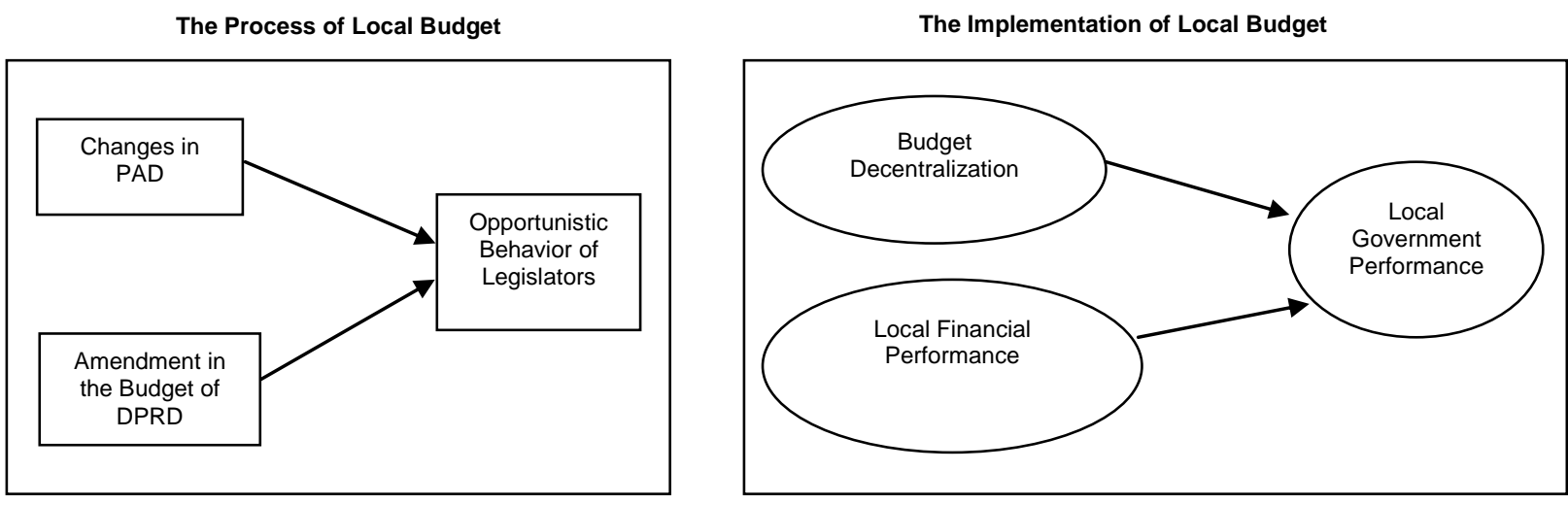

Figure 1 - Research Framework

Operational Definition for Amendment in the Budget of DPRD. In budgeting, conflicts happen between the legislature (principal) with government / local government (agent) in the case of: 1) preparation of APBD, especially in the post of budget for DPRD; 2 ) the position of DPRD budget to PAD; 3 ) the position of protocol for legislators and their facilities; and 4) the discussion of the annual accountability report by the regional head (Yudhoyono, 2004: 39). DPRD has different preferences with executives on the total budget for DPRD, education, health, and infrastructure (Abdullah, 2004). Operational definition of variable of DPRD budget amendment (PDPRD) in this study was calculated from the percentage of the increase in DPRD budget and the secretariat budget of the current year reduced by DPRD budget and the secretariat budget of the previous year.

Operational Definition for Opportunistic Behavior of the Legislators. Results of research by Tanzi and Davoodi (2002) provide evidence of opportunistic behavior of politicians in making decisions on public investment. The politicians make decisions related to ((1) the 
amount of the public investment, (2) the composition of the public investment, (3) the selection of specific projects and location, and (4) the design of each public investment project. The decisions are related to the contracts given to outside parties, which can produce rente in the form of commissions. Operational definitions of opportunistic behavior $(\mathrm{OL})$ in this study is: 1) calculating the spread of budget for education ( $\Delta \mathrm{Pdk})$, health ( $\Delta \mathrm{Kes})$, public works $(\Delta \mathrm{PU})$, and DPRD ( $\Delta$ Leg) and; 2) accumulating $\Delta \mathrm{Pdk}, \Delta \mathrm{kes}, \Delta \mathrm{PU}$, and $\Delta$ Leg.

Operational Definition for Budget Decentralization. There are three indicators for budget decentralization based on empirical findings. First, it is measured by the ratio of the total expenditure of each regencies / cities (APBD) to total government expenditure (APBN) (Phillips and Woller, 1997; Zhang and Zou, 1998). Second, it is measured by the ratio of the total development expenditure of regencies / cities (APBD) to total national development expenditure (APBN) (Zhang and Zhou, 1998). The local government is authorized to determine the allocation of the expenditure which is to increase local revenue (PAD).

Operational Definition for Local Financial Performance. There are some measures in government organizations to measure the financial performance, i.e. independence ratio, effectiveness ratio, efficiency ratio, and growth ratio (Halim, 2007). Local independence ratio is interpreted by comparing the total revenue (PAD) toward $\mathrm{DAU}^{7}$ (Halim, 2007: 232; Uchimura and Suzuki, 2009; Bird, 1993; and Khusaini, 2006. Local effectiveness ratio refers to the comparison of realized local revenues toward the target set by the real potential of the area (Halim, 2007: 234). Local efficiency ratio refers to the ratio between the total expenditure toward total revenue (Halim, 2007: 234). Local growth revenue ratio is calculated by subtracting the revenue of the year with the revenue of the previous year (Halim, 2007: 241).

Financial performance of local government is said to be good if the management is independent or less dependence on the central government in the use of sources of local income. It is effective in achieving the realization of the targets that have been planned, meaning that the use of the budget is based on the target. It is efficient in activities and budget, meaning that spending is only intended for the main programs or priorities of development directly, and is coupled with the increase in the sources of the income. Finally, local revenue increases from year to year.

Operational Definition for Local Government Performance. Local Government Performance is based on welfare and is defined as success in improving public services. Achievement of basic needs for the people is reflected in the Human Development Index (HDI) (Lindahman and Thurmaier, 2002). The united National Development Program (UNDP) has been using this index since 1990 to measure the achievement of human development of a country. Although it cannot measure all dimensions of development, but it is able to measure basic dimensions of human development thought as the reflection of the status of basic capabilities of population (Chiristy and Adi, 2009).

However, the application of $\mathrm{HDI}$ as the measure of the public service if supported with adequate local infrastructure will accelerate the improvement of public services. Performance is said to be good if local governments increased public services; increased community service can be indicated by the increased budget for health for the sake of increasing Life Expectancy Index, by the increased budget for education for the sake of increasing Education Index, and by the increased budget for infrastructure for the enhancement of the Regional Infrastructure Development Index.

\section{RESEARCH HYPOTHESES}

The Effect of Change in PAD toward Opportunistic Behavior of Legislators. The preference of legislators is on infrastructure projects because it is easier to use for the fulfillment of their campaign promise to their voters (Keefer and Khemani, 2003). Education and health are basic needs that should be given by the government, both central and local,

\footnotetext{
${ }^{7}$ Dana Alokasi Umum, translated as General Allocation Fund.
} 
and influence economic growth (Davoodi et al., 2003; Gupta et al., 2002). The increase on PAD brings positive effect on the budget allocation for DPRD (Abdullah, 2004).

The findings of the previous study by Sularso and Restianto (2011) in the Province of Central Java are as follows. First, the larger the amount of revenue by regencies or cities, the greater the opportunistic behavior in the budgeting process is. Second, the greater the number of SiLPA in the budgeting of regencies or cities, the greater the opportunistic behavior is. The greater the amount of DAU received by regencies or cities, the greater the opportunistic behavior is. Thus, the first hypothesis in this study is:

$\mathrm{H} 1$ : The change in PAD affects opportunistic behavior of legislators.

The Effect of Amendment in the DPRD Budget toward Opportunistic Behavior of Legislators. Differences in preferences between the executive and the legislative in budget allocation will result in Opportunistic Behavior of the legislators. DPRD can force the executives in sectorial expenditure allocations. Allocation for infrastructure and DPRD is proposed to increase, but the allocation for education and health is decreased. Enormous discretionary power of legislative in terms of supervision and budget causes discretion over the use of the DPRD budget not in accordance with public preferences (Abdullah, 2004). Previous finding by Colombatto (2001) state that changes in DPRD budget affects the Opportunistic Behavior of the legislators. Thus, in this study, the second hypothesis proposed is:

$\mathrm{H} 2$ : Amendment in the DPRD budget affects Opportunistic Behavior of legislators.

The Effect of Budget Decentralization toward Local Financial Performance. The results of the research by Andros M P Hasugian (2006) entitled "The Impact of Fiscal Decentralization toward the Regional Financial Performance and Poverty in the Cities and Regencies of West Java Province" show that the central government's fiscal decentralization is the right step. In addition to revenue increase, fiscal decentralization also reduces poverty. Indication on the dependence of local governments on the central government is still high.

The mechanism of transfer of the central government can reduce the gap with the local governments, but not the gap between regions (Sumedi, 2005). Independence level decreases after decentralization, while PAD levels of urban areas are greater than other areas do (Pakasi, 2005).

Structural expenditure of each regencies or cities in Banten is reflected in the extent to which direct spending dominates routine spending. Ideally, local government budget should be used for development spending rather than for others. The findings by Demelo (2000) show decentralization of government budget will increase knowledge about the characteristics and needs of local communities. This knowledge will encourage more areas to be independent, effective, and efficient, as well as encourage public accountability and transparency in the provision of public services and more democratic decision-making. Thus, in this study, the third hypothesis proposed is:

H3: Budget decentralization affects local financial performance.

The Effect of Budget Decentralization toward Local Government Performance. The findings by Phillips and Woller (1997) show that budget decentralization does not affect the performance of local governments. Budget decentralization can actually create an opportunity for local governments to undertake less responsible and less sustainable spending, if it is done without institutional readiness of administration and bureaucracy as well as adequate human resources. It is better for local governments to be able to identify and meet the needs of local communities (local needs) as the local governments are closer to the people (Musgrave, 1959; and Oates, 1993). Local government spending must be based on main programs or priorities in order to meet local needs, and should be directed to the improvement of services to the community.

The findings are in contrast with the ones by Lindahman and Thurmaier (2002), revealing that budget decentralization brings positive effect on the fulfillment of basic needs for the community (basic needs, better education, and healthier population). Fulfillment of basic needs that are better tailored will produce individual and social welfare, as well as the reflection of good government performance. This can happen because budget decentralization will allow local governments to mobilize and utilize local resources more 
easily as to improve public services as a measure of government performance (Peterson, 1994). Thus, in this study, the fourth hypothesis proposed is:

$\mathrm{H} 4$ : Budget decentralization affects local government performance.

The Effect of Local Financial Performance toward Local Government Performance. The findings of the study by Ardhini and Hand (2011) show that in the perspective of the Agency Theory proves that the ratio of local independence brings a positive non-significant effect to the ratio of capital expenditures for public services; the ratio of the local finance effectiveness brings positive effect on capital expenditure for public services; the ratio of local finance efficiency brings a negative non-significant effect on capital expenditure for public services; and the rest of the previous year budget (SiLPA) brings a positive and significant effect on the realization of capital expenditures for public services. Thus, in this study, the fifth hypothesis proposed is:

H5: Local financial performance affects local government performance.

\section{METHODS OF RESEARCH}

This study is quantitative with secondary data source with scale ratio data. This study uses hypothesis-testing model. Selection of study design is to test the hypothesis empirically for direct and indirect influence, or to give an explanation or a causal relationship between the variables studied by testing hypotheses (confirmatory research) (Sekaran, 1992).

Population is the generalization region of the object and the subject that has certain qualities and characteristics defined by the researchers to learn and then be deduced (Sekaran, 1992). The population in this study was the regencies and cities in the Province of Banten. The sample size was the entire study population (census) comprising of four regencies and four cities. The regencies were Lebak, Pandeglang, Serang, and Tangerang. The cities were Tangerang, Cilegon, Serang, and Tangerang. Data was obtained from the Accountability Report of the Mayor already put in Regulations and Budget Realization Report (LRA) from 2009 to 2014.

Data was obtained from DPKD, Bappeda, and BPS ${ }^{8}$ Banten. Type of research data was a panel data covering cross section data and time series. Scale type of the data in this study was ratio scale, the scale of which has a value-based that cannot be changed. This ratio also has a numeric value, order, distance and an initial value (origin) (Hartono, 2007).

The analysis technique used by the Agency Theory in the budgeting process of local government in this study was Path Analysis, given all the variables can be categorized as observable variables. For analysis on the implementation of local government budget, Partial Least Square (PLS) was used as the category was unobservable. Partial Least Square (PLS) is a soft modeling method of analysis because it does not ask the data to be specific to the measurement scale, which means the number of samples can be small, or below 100 samples (Widodo, 2006). The use of PLS in this phase is because PLS can be used to confirm the theory of the relationship between variables and to recommend relationship of variables whose theoretical concept or empirical support are weak. In addition, PLS does not require many assumptions, the sample size should not be large and can be applied at all scales of data (Widodo, 2008).

\section{FINDINGS AND DISCUSSION}

Changes in PAD have no direct effect toward Opportunistic Behavior of the legislators. The hypothesis testing results produced a path coefficient of 0.042 , T-Statistic of 0.702 smaller than $1.960(0702<1.960)$, and P-value of 0.486 that is greater than that required by 0.05 (0.486 > 0.05). This implies that although revenue of regencies / cities in Banten increased from year to year, it does not contribute to opportunistic behavior of the legislators, as the mechanism of PAD has been integrated with the system of public service.

\footnotetext{
${ }^{8}$ Biro Pusat Statistik, translated as Central Bureau of Statistics
} 
Changes or amendment in DPRD budget positively affects Opportunistic Behavior of the legislators. The hypothesis testing results produced a path coefficient of 0.912 , meaning very strong. Then, T-Statistic of 15.385 is greater than that required by 1.960 (15.358 > 1.960). The P-value of 0.000 was less than $0.05(0.000<0.05)$. The results of this study confirm the results of previous findings (Abdullah, 2004) that DPRD budget changes affect the Opportunistic Behavior of the legislators. Government Regulation Number 37 of 2005 regulating the financial position of legislators indirectly gives motivation for legislators to misallocate the budget when the amount is associated with local financial capacity (measured from the amount of PAD). The Government Regulation is not run properly, and it is used as a justification to allocate an even bigger legislative budget. It shows that the legislators allocate funds for their benefit exceeding the amount allowed in the regulation (Jaya, 2005). Preferences of the legislators is to amend the budget by raising the infrastructure budget and the budget for them (DPRD) while lowering education and health budget; and this has led to the greater chance of occurrence of opportunistic behavior by legislators.

The statistical results show a path coefficient of 0.973 , T-Statistic of $55.980>1.960$, and P-value of $0.000<0.05$, and using a cut-off value of T-table at 1.960 (Ghozali, 2006: 31), the study shows budget decentralization affects the local financial performance. These results support the previous findings by Andros M P Hasugian (2006). Thus, the central government's policy to fiscal decentralization is the right step. In addition to revenue generation, fiscal decentralization policies also reduce poverty. This indicates the dependence of local governments on the central government is still high. The central government as the representative of the local governments gives fiscal authority and the transfer of funds to local governments (agents) supervised by DPRD (the principal) to be managed in accordance with the priorities. This way, the management is more efficient and is able to increase revenue for the welfare of society.

Results of statistical on the effect of budget decentralization toward local government performance shows the coefficient value of 0.083 , T-Statistic of 0.315 smaller than the Ttable $(0.315<1.960)$, and P-value of 0.315 greater than 0.05 . These results suggest that budget decentralization does not affect the local government performance. Local government expenditure is related to the balanced funds and PAD as one of the basic capital for local governments that are not able to reach and improve the performance of local government. Local government performance is intended for public sector services, i.e. health, education, and local infrastructure for the welfare of the society. These results confirm previous findings by the World Bank (1997) that budget decentralization in developing countries, if not matched with the quality of personnel and political accountability, will only create bad and corrupt government and poor public services. This will be worse if the budget decentralization policy is taken without a clear political consensus and the readiness of administration and appropriate legal instruments. Further budget decentralization can actually create an incentive for local governments to undertake less responsible and sustainable spending, if the application is without institutional readiness, both administration and bureaucracy, and if there are not adequate human resources (Phillips, 1997).

The analysis on the effect of regional financial performance on the Local Government performance generates a path coefficient value of 0.767 and the value of the T-Statistic greater than the T-table $(8,872>1,960)$ with a P-value of 0.000 . These results confirm previous findings by Dawn and Ghozali (2013) that regional financial performance affects the performance of local governments. This means if the capital expenditure is addressed to the public service, then budget decentralization can encourage economic efficiency and dynamically will encourage the economic growth of the region, so the impact of economic efficiency and economic growth will improve public services as a good indicator of government performance (Martinesz and Mc Nab, 1997).

Meanwhile, in terms of the results of analysis on the perspective of the agency theory in the process of local government budgeting, facts discovered show that the composition of DPRD budget each year has experienced substantial increases annually in an average of $25.5 \%$. This increase is not proportional to the increase of annual revenue. Government 
Regulation Number 37 of 2005 regulating the financial position of legislators indirectly gives motivation for legislators to misallocate the budget when the amount is associated with local financial capacity (measured from the amount of PAD). The Government Regulation is not run properly, and it is used as a justification to allocate an even bigger legislative budget.

Besides DPRD budget allocation, infrastructure budget allocation for regencies / cities in Banten has also experienced a considerable rise in an average of $30.05 \%$ per year; it is allocated for the construction of facilities and infrastructure services to the public. Work on these projects is generally done by a third party through an auction with legislative and executive intervention. Allocation of fund for infrastructure and DPRD is deliberately increased, but allocation of fund for education and health declines. The composition of DPRD budget and the infrastructure budget for the regencies / cities in Banten continuously increases every year and this has led to the assumption of misallocation of budget for the interest of DPRD. These findings confirm the findings by Colombatto (2001). The tendency of misallocation in government expenditure is part of a political battle between the politicians and executives, which obviously has never benefit the poor. When the allocation decisions are made, their motivation to output budget is rent seeking. Their preferences are to onduct budgetary slack, even commit moral hazard.

Moreover, the results of analysis on the perspective of the agency theory in the implemetation of local government budget. The composition of expenditure for regencies / cities in Banten reveals substantive and structural expenditure, cost allocation budget for the local bureaucracy, and bigger routine expenditure than capital expenditures. This is consistent with the findings by Eko (2006) that of the eight regencies / cities, indirect expenditure on average absorbs 60.5 percent of personnel expenditure. Part of it is allocated to direct expenditure, but the composition of its development expenditure is only $12.5 \%$ of its overall APBD.

Contribution of DAU during the period of analysis, from 2009 to 2014, is still very high, in average accounted for $62.5 \%$ of the revenue. This shows the lower level of independence of the regions; the tendency is the decline in the ratio of PAD to revenue. DAK ${ }^{9}$ of regencies / cities in Banten is relatively small when compared to DAU. Under the rules, DAK is only used to finance the physical activities or projects, and they should be supported by at least $25 \%$ of local budget. Logically, the greater the DAK, the greater the capital expenditure is, and it directly affects the performance of local government.

\section{CONCLUSION}

The Results of Analysis on the Perspective of the Agency Theory in the Process of Local Government Budgeting. The PAD change does not affect the Opportunistic Behavior of the legislators. This means that the increase in local revenue (PAD) of regencies / cities in Banten from year to year does not contribute to opportunistic behavior of the legislators, as local revenue is collected through direct transfers to local government bank accounts that have been integrated with the system of service and admission revenue.

Moreover, the amendment in DPRD Budget affects the Opportunistic Behavior of the legislators. This means that the Government Regulation Number 110 of 2000 as amended by Government Regulation Number 24 of 2004, subsequently amended by Government Regulation Number 37 of 2005 which regulates the finance position of legislators, indirectly giving motivation to the them to misallocate the budget when the amount of expenditure for legislative is associated with local financial capacity (measured from the amount of PAD).

The Results of Analysis on the Perspective of the Agency Theory in the Implemetation of Local Government Budget in the Province of Banten. Budget decentralization affects the regional financial performance. This means that the central government as the representative of the local government gives fiscal authority and the transfer of funds to local governments (agents) supervised by DPRD (the principal) to be managed in accordance with the priorities.

\footnotetext{
${ }^{9}$ Dana Alokasi Khusus, translated as Special Allocation Fund
} 
This way, the management is more efficient and is able to increase revenue for the welfare of society.

The Perspective of the Agency Theory. The results of this analysis can be seen from the executive pro-people policies. The results of a comparative analysis on the amount of routine and development expenditures on items of direct and indirect expenditure in the budget shows the government allocates a bigger budget for routine expenditure than for development expenditure (capital expenditure).

Budget decentralization statistically does not affect the local government performance. This means that fiscal authority and the transfer of funds by the central government to local governments (agents) that are supervised by DPRD (the principal) as a unit in the system is not able to increase the Local Government Performance directly.

The results of this analysis show the tendency that budget allocation in local government is part of the political fighting among politicians, those pro and contra to the poor. When the allocation decisions are made, the legislative preferences related to expenditure trigger moral hazard.

The results of this study show that financial performance statistically affects local government performance. The high dependence on transfer of funds to the central government does not affect the performance of local governments. It implies that the local government should be more careful in using the revenue from the community rather than funds transfer (grant) received from the central government.

The results of analysis of this study reveal that supervision of DPRD is on the political dimension and not on the professional dimension of administration conducted by functional supervisors. DPRD emphasizes supervisory duties in terms of the use of executive power than the real living conditions of the people, of whether executives in their activities have benefited the people (voters) or whether the people have obtained proper services.

\section{SUGGESTIONS}

The success on the implementation of budget decentralization depends on the design tailored to the characteristics of each local authority, although it is designed to be uniform (default) by the central government.

Changes in the model or system of governance from centralization to decentralization in Indonesia obviously require a change in mindset and behavior of government officials in regencies / cities in Banten.

\section{REFERENCES}

1. Abdullah, Syukriy. 2004. Perilaku oportunistik legislatif dalam penganggaran daerah Pendekatan principal-agent theory. Seminar Antar Bangsa di Universitas Bengkulu, Bengkulu, 4-5 Oktober 2004.

2. Abdullah, Syukriy dan Asmara, John Andra, 2006. Perilaku Oportunistik Legislatif dalam Penganggaran Daerah; Bukti Empiris atas Aplikasi Agency Theory di Sektor Publik. Simposium Nasional Akuntansi 9. 23-26 Agustus 2006. Padang.

3. Adi, Priyo Hari. 2005. Dampak Desentralisasi Fiskal terhadap Pertumbuhan Ekonomi. Jurnal Kritis. Universitas Kristen Satya Wacana. Salatiga.

4. Ardhini dan Handayani. 2011. "Pengaruh Rasio Keuangan Daerah Terhadap Belanja Modal Untuk Pelayanan Publik Dalam Perspektif Teori Keagenan. Jurnal Fakultas Ekonomi Universitas Diponegoro. Semarang.

5. Andros M P Hasugian, 2006. Dampak Desentralisasi Fiskal terhadap Kinerja Keuangan Daerah dan Kemiskinan di Kabupaten dan Kota Provinsi Jawa Barat. Jurnal Departemen ilmu Ekonomi Fakultas Ekonomi Dan Manajemen Institut Pertanian Bogor, Bogor.

6. Bird, R.M, Robert Ebel dan Christine Wallich. 1995. Decentralization of the Socialist State: Intergovernmental Finance in Economies, Economic Department Working Paper Word Bank. Washington DC.

7. Boediono, 1988. Teori Pertumbuhan Ekonomi, Penerbit BPFE, Yogyakarta. 
8. Christensen, Jorgen Gronnegard. 1992. "Hierarchical and contractual approaches to budgetary reform". Journal of Theoretical Politics 4 (1): 67-91.

9. Christy, Fhino Andrea dan Priyo Hari Adi, 2009. "Hubungan Antara Dana Alokasi Umum, Belanja Modal dan Kualitas Pembangunan Manusia" The $3^{\text {rd }}$ National Conference UKWMS, October $10^{\text {th }}$, Surabaya.

10. Colombatto, Enrico. 2001. Discretionary power, rent seeking, and corruption. Working Paper University di Torino dan ICER (International Center for Economic Research), Italy.

11. Darwanto, dan Yulia Yustikasari. 2007. Pengaruh Pertumbuhan Ekonomi, Pendapatan Asli Daerah, dan Dana Alokasi Umum terhadap Pengalokasian Anggaran Belanja Modal, Simposium Nasional Akuntansi X Makasar.

12. Davoodi, H., D. Xie and Heng-fu Zou. 1998. "Fiscal Decentralization and Economic Growth: A Cross Country Study."Journal of Urban Economics 43 (2): 244-257, and Policy Research Department, the World Bank, N10-075, 1818 H St. NW, Washington, DC. 20433.

13. Davoodi, Hamid R, Erwin R. Tiongson, \& Sawitree S. Asawanuchit. 2003. How useful are benefit incidence analyses of public education and health spending? IMF Working Paper WP/03/227. Washington, DC.

14. De Mello JR, Luiz R. 2000. Fiscal Decentralization and Intergovernmental Fiscal Relations: A Cross-Country Analysis; Journal Elsevier Science Ltd, World Development, Vol. 28, No. 2, pp. 365 $\pm 380,2000$ Ó2000; All rights reserved Printed in Great Britain.

15. Dobell, Peter dan Martin Ulrich. 2002. Parliament's performance in the budget process: $A$ case study. Policy Matters 3(2): 1-24. http://www.irpp.org.

16. Eisenhardt, Kathleen M. 1989: Agency Theory; An Assessment and review. Journal The Academy of Management Review, Vol. 14, No 1, pp. 57-74. Published by; Academy of Management. Stable URL: http://www.jstor.org/stable/258191. Page Count: 18

17. Eko, Sutoro, 2006. Menuju Kesejahteraan Rakyat Melalui Desentralisasi, Insight Working Paper; Institute For Research and Empowerment (IRE'S), Vol.I, Maret. Yogyakarta.

18. Fajar Hidayat, Mochamad dan Ghozali Maski. 2013. Analisis Pengaruh Kinerja Keuangan Daerah terhadap alokasi belanja modal (studi pada kabupaten dan kota di Jawa Timur) Jurnal Ilmiah Fakultas Ekonomi dan Bisnis Universitas Brawijaya, Malang.

19. Freddy, Situngkir, Sirojuzilam, Erlina, dan Suriadi Agus. 2014" Pengaruh Desentralisasi Fiskal terhadap Pertumbuhan Ekonomi di Provinsi Sumatra Utara". Jurnal Ekonomi, Vol 17 No.3, Juli 2014; Fakultas Ekonomi Universitas Sumatra Utara; Medan.

20. Garamfalvi, L. 1997. Corruption in the public expenditures management process. Paper presented at 8th International Anti-Corruption Conference, Lima, Peru, 7-11 September. :http://www.transparency.org/iacc/8th_iacc/papers/garamfalvi/garamfalvi.html

21. Ghozali, Imam. (2006), Aplikasi Analisis Multivariate dengan Program SPSS,edisi 4: Penerbit Badan Penerbitan Universitas Diponegoro, UNDIP, Semarang.

22. Ghozali, Imam. 2008. Model Persamaan Struktural Konsep dan Aplikaasi dengan program Amos 16.0, Badan Penerbitan Universitas Diponegoro, UNDIP, Semarang.

23. Ghozali, Imam. 2008. Structural Equation Modeling Metode Alternatif dengan Partial Least Square, edisi kedua: Universitas Diponegoro, UNDIP Semarang.

24. Groehendijk, Nico. 1997. "A principal-agent model of corruption". Journal Crime, Law and Social Change 27: 207-229, Cite this article as oi:10.1023/A:1008267601329.

25. Gupta, Sanjeev, Hamid Davoodi, \& Erwin R. Tiongson. 2002. Corruption and the provision of health care and education services, dalam Abed, George T. and Sanjeev Gupta (eds.). 2002. Governance, Corruption, and Economic Performance.http://www.imf.org/external/pubs/nft/2002/govern/.

26. Halim, Abdul, 2007. Akuntansi Sektor Publik: Akuntansi Keuangan Daerah: Salemba Empat, Jakarta.

27. Hamzah, Ardi. 2008. Analisis Kinerja Keuangan terhadap Pertumbuhan Ekonomi, Pengangguran dan Kemiskinan: Pendekatan Analisis Jalur. Simposium Nasional Akuntansi XI, Pontianak.

28. Hartono, Jogiyanto. 2007. Metode Penelitian Bisnis; Salah Kaprah dan PengalamanPengalaman; Penerbit; BPFE, Yogyakarta. 
29. Jaya, Wihana Kirana, 2005.Dysfunctional institutions in the case of local elite behavior in decision-making about local government budgets in Indonesia.Jurnal Ekonomi dan Bisnis Indonesia 20(2): 120-135.

30. Jackson, P. M. 1982. "The Political Economy of Bureaucracy". Philip Allan Press; Oxford, USA.

31. Jogiyanto, H.M, dan Abdillah, W. 2009. Konsep dan Aplikasi PLS (partial least square) untuk penelitian empiris; Penerbit BPFE, Yogyakarta.

32. Johnson, Cathy Marie. 1994. The Dynamics of Conflict between Bureaucrats and Legislators; M.E. Sharpe; Armonk, New York.

33. Keefer, Philip \& Stuti Khemani. 2003. The political economy of public expenditures: Making Service Work for Poor People; Background paper for WDR 2004 The World Bank; Washington DC.

34. Kuncoro, Mudrajat. 2004. Otonomi dan Pembangunan Daerah: Reformasi, Perencanaan, Strategi dan Peluang. Penerbit Erlangga.

35. Kuncoro, Mudrajat. 2004. Metode Kuantitatif: Teori dan Aplikasi untuk Bisnis dan Ekonomi. Penerbit; Unit Percetakan AMP YKPN, Yogyakarta.

36. Khusaini, Muhamad, 2006. "Desentralisasi Fiskal dan Pembangunan Daerah" Jurnal BPFE Fakultas Ekonomi dan Bisnis; Universitas Brawijaya, Malang.

37. Lindahman, Kara and Kurt Thurmaier, 2002. Beyond Efficiency and Economy: An Examination of Basic Needs and Fiscal Decentralization, Journal; The University of Chicago, USA.

38. Lupia, Arthur dan Mathew McCubbins. 2000. Representation or abdication? How citizens use institutions to help delegation succeed. European Journal of Political Research 37: 291-307.

39. Lin, Justin Yifu dan Liu, Zhiqiang. 2000. "Fiscal Decentralization and Economic Growth in China". Journal Economic Development and Cultural Change. Vol 49. Hal :1 - 21. Chicago.

40. Mankiw N. Gregory. 1999. Macroeconomics, 4 th Edition, Worth Publisher, 41 Madison Avenue, New York.

41. Martinez Vazquez, Jorge. M and McNab, R. 2001. Fiscal Decentralization, Economic Growth, and Democratic Governance, Working Paper, October, 1-41.

42. Martinez Vazquez, Jorge dan Robert M Mc Nab. 2007. "Fiscal Decentralization, Macro stability and Growth ; International Studies Program Working Paper, 05-06; Georgia State University, Andrew Young School of Policy Studies, Atlanta GA.

43. Musgrave, R.A. 1959. The Theory of Public Finance. A Study In Public Economy. McGraw-Hill Book Company. Inc,. Kogakusha Company Ltd. Tokyo.

44. Nana Putri Ani, Ni Luh., Dwirandra, A.A.N.B, 2014. Pengaruh Kinerja Keuangan Daerah pada Pertumbuhan Ekonomi, Pengangguran dan Kemiskinan Kabupaten dan Kota. EJurnal Akuntansi 6.3 (2014): Hal 481-497. Fakultas Ekonomi dan Bisnis universitas Udayana, Bali.

45. Oates, W.E. 1993. "Fiscal Decentralization and Economic Development." National tax, Journal 46 (3): 237-243.

46. Pakasi, C., 2005. Dampak Desentralisasi Fiskal terhadap perekonomian kabupaten dan kota di Provinsi Sulawesi Utara. Disertasi Doktor (tidak dipublikasikan), IPB, Bogor.

47. Peterson, B. Stephen. 1994. Budgeting in Kenya: Practice and Prescription, Public Budgeting dan Finance. Vol. 14, N0.3, Pages 55-76.

48. Phillips, Kerk. L and Woller, Garry. 1997. Does Fiscal Decentralization Lead to Economic Growth?, Working Paper, Number 97-7, September, 1-13.

49. Republik Indonesia, 2005. Peraturan Pemerintah Nomor 37 Tahun 2005; tentang Kedudukan Keuangan Anggota Legislatif.

50. Riduan dan Kuncoro, Engkos Ahmad, 2011. "Cara Mudah Menggunakan dan Memakai Path Analysis (Analisis Jalur)". Penerbit ALFABETA, Bandung.

51. Samuels, David. 2000. Fiscal horizontal accountability? Toward theory of budgetary" checks and balances" in presidential systems; University of Minnesota, working paper 
presented at the Conference on Horizontal Accountability in New Democracies, University of Notre Dame, May.

52. Saragih, Juli Panglima. 2003. Desentralisasi Fiskal dan Keuangan Daerah dalam Otonomi.Penerbit Ghalia Indonesia. Jakarta.

53. Sekaran, U.1992. Reaserch Methods For Business: A Skill Building Approach, Second Edition, John Wiley dan sons, Inc. USA.

54. Setiaji, Wirawan dan Priyo Hari Adi. 2007. Peta Kemampuan Keuangan Daerah Sesudah Otonomi Daerah: Apakah Mengalami Pergeseran?, Simposium Nasional Akuntansi X Makasar.

55. Smith, Robert W. \& Mark Bertozzi. 1998. "Principals and agents: An explanatory model of public budgeting. Journal of Public Budgeting, Accounting, and Financial Management (Fall): 325-353.

56. Stannia Cahaya Suci. 2013. Pengaruh Kemandirian Keuangan Daerah Terhadap Pertumbuhan Ekonomi Dan Kemiskinan Kabupaten/Kota Provinsi Banten. Departemen Ilmu Ekonomi; Jurnal Fakultas Ekonomi dan Manajemen Institut Pertanian Bogor; Bogor.

57. Stephen M., Russek, Frank S., 1997. "Fiscal Structures and Economic Growth at The State and Local Level", Public Finance Review, Vol. X 25 No. 2, 213 - 237.

58. Sularso. Havid dan Restianto. Yanuar E, 2011. "Pengaruh Kinerja Keuangan terhadap Alokasi Belanja Modal dan Pertumbuhan Ekonomi Kabupaten/Kota di Jawa Tengah". Media Riset Akuntansi, Vol.1. No 2 Agustus 2011. Fakultas Ekonomi Universitas Jenderal Soedirman, Grendeng, Purwokerto.

59. Sumedi, 2005. Dampak Kebijakan Desentralisasi Fiskal terhadap Kinerja sektor pertanian. Tesis Magister sain (tidak dipublikasikan) Pascasarjana IPB, Bogor.

60. Tanzi, Vito, and Hamid Davoodi, 2002."Corruption, public investment, and growth", dalam Abed, George T. and Sanjeev Gupta (eds.). 2002; Work Paper Governance, Corruption, and Economic Performance; International Monetary Fund. Washington, D.C.

61. Uchimura, Hiroko dan Suzuki, Yurika, 2009. Measuring Fiscal Decentralization in the Philippines; IDE-JETRO Papers are Preliminary Materials Circulated to Stimulated Discussions and Critical Comment. Institute of Developing Economies.

62. Usman, 2006. "Dampak Desentralisasi Fiskal terhadap Distribusi Pendapatan dan Tingkat Kemiskinan", Jurnal IImu Ekonomi Pertanian IPB, Bogor Indonesia.

63. Von Hagen, Jurgen. 2002. Fiscal Rules, Fiscal Institutions, and Fiscal Performance; Journal The Economic and Social Review 33 (3): 263-284.

64. World Bank. 1997. The World Development Report, New York, Oxford University Press. USA.

65. World Bank. 1997. On Line Source book on Decentralization and Rural Development, Decentralization Thematic Team; Oxford University Press. New York, USA.

66. Yudhoyono, S.B. 2004. Pembangunan Pertanian dan Pedesaan sebagai Upaya Mengatasi Kemiskinan dan Pengangguran: Analisis Ekonomi Politik Kebijakan Fiskal. Disertasi Doktor (tidak dipublikasikan) Pasca Sarjana IPB, Bogor.

67. Zhang Tao and Zou Heng-fu. 1998. Fiskal Decentralization, Public Spending, and Economic Growth in China, Journal of Public Economics 67, 221-240.

68. Zhang Tao and Zou Heng-fu. 2001. The Growth impact of Inter-sectorial and intergovernmental Allocation of Public Expenditure: with Application to China and India, Economic Review, Vol. 12, 58-81. China. 